\title{
PERAN AUDIT INTERNAL DALAM PENCEGAHAN FRAUD DI PERGURUAN TINGGI : LITERATURE REVIEW
}

\author{
Maya Aresteria \\ Satuan Pengawas Internal, Universitas Diponegoro \\ J1. Prof. Soedarto, SH. Tembalang- Semarang \\ email: mayaaresteria3@gmail.com
}

\begin{abstract}
Abstrak
Tujuan dari artikel ini adalah untuk melihat peran audit internal dalam mencegah terjadinya fraud di perguruan tinggi berdasar metode Literature Review. Penerapan sistem internal control yang baik di perguruan tinggi dapat meningkatkan kontrol terhadap kemungkinan terjadinya fraud, karena itu maka tim internal audit harus memiliki komoetensi dalam menjalankan tugas dan fungsinya dalam pengawasan. SPAI- Standar no 120.22004 menyebutkan bahwa internal auditor harus memiliki pengetahuan untuk mengenali, meneliti, serta menguji adanya fraud. Ketika internal audit memiliki fungsi kontrol yang baik dan juga memiliki peran penting dalam manajemen perguruan tinggi, maka kemungkinan terjadinya fraud dapat dicegah.
\end{abstract}

Kata kunci: audit internal, kontrol, pencegahan, fraud, perguruan tinggi

\begin{abstract}
The aim of this article is to see the role of internal audit in order to prevent fraud in University based from literature review. A good implementation of internal controlling system in university can improve controlling towards fraud possibilities as an implementer of internal audit in university must have competencies on their duty. SPAI - standard of 120.22004 stated that internal auditors must have knowledge to recognize, to research and to test the existence of fraud. When audit internals have a good control and also have important roles in university's management, the existence of fraud can be prevented.
\end{abstract}

Keywords: internal audit, control, prevent, fraud, university

\section{Pendahuluan}

Perguruan Tinggi merupakan penyelenggara pendidikan tinggi. Pada era globalisasi saat ini, Perguruan Tinggi dituntut untuk mampu menjaga kelangsungan hidupnya, yaitu dengan meningkatkan kemampuan produktivitasnya. Perguruan Tinggi merupakan entitas ekonomi yang mengelola dana bersumber dari masyarakat, perorangan, dan pemerintah. Oleh karena itu, Perguruan Tinggi memiliki kewajiban menyampaikan laporan keuangan secara berkala atas pengelolaan sumber dana tersebut. Tuntutan transparansi dan akuntabilitas juga mendorong pihak manajemen untuk menghasilkan laporan berkualitas yang bebas dari penyimpangan.

Pengawasan yang lebih ketat perlu dilakukan dalam upaya mencegah terjadinya perilaku penyimpangan melalui peningkatan sistem pengendalian internal dalam manajemen Perguruan Tinggi ( Dewi dan Apandi, 2011). Dalam melakukan pengawasan pada pengendalian internal, Perguruan Tinggi memiliki bagian Satuan Penjaminan Mutu dan Satuan Pengendalian Internal atau auditor internal yang memiliki tugas untuk melakukan audit dalam bidang manajemen keuangan, akademik, dan sumber daya (Dewi dan Apandi, 2011). Audit internal menyediakan analisis, penilaian, rekomendasi, dan informasi sehubungan dengan aktivitas unit yang diaudit sehingga dapat menghasilkan nilai tambah dalam kegiatan organisasi yang pada akhirnya mencapai tujuan dari organisasi.

Fokus artikel ini adalah pengendalian internal dalam bidang non akademik, dimana pada bidang non akademik auditor internal berperan sebagai supporting activity seperti pada keuangan, asset, sumberdaya manusia, organisasi serta kemahasiswaan. 
Pada saat ini biaya pendidikan di perguruan tinggi terbilang cukup tinggi, sehingga dana yang dikelola oleh perguruan tinggi menjadi tidak sedikit. Hal tersebut memicu kerawanan dalam munculnya fraud, baik itu penyalahgunaan asset (Asset Misappropriation) karena jumlah asset di perguruan tinggi cukup banyak, fraud dalam biaya penerimaan mahasiswa, fraud dana penelitian, maupun fraud dalam pengelolaan keuangan lainnya dalam perguruan tinggi. Pimpinan perguruan tinggi melalui internal audit harus mampu mengklasifikasikan kecurangan tersebut sehingga diperlukan upaya untuk dapat mendeteksi, mencegah, serta menginvestigasi terjadinya fraud.

Zakaria, Susela dan Zarina (2006) melakukan penelitian dengan mengambil sampel lembaga perguruan tinggi, yaitu 17 perguruan tinggi negeri, dan 49 perguruan tinggi swasta di Malaysia. Penelitian tersebut bertujuan untuk memberikan bukti tentang pembentukan fungsi internal audit pada lembaga pendidikan tinggi di Malaysia dan juga untuk mendapatkan persepsi manajemen terhadap peranan dan ruang lingkup audit internal. Dalam penelitian tersebut mengungkapkan pentingnya audit internal di perguruan tinggi dan karenanya kementerian pendidikan harus mempertimbangkan keharusan setiap lembaga perguruan tinggi memiliki fungsi audit internal.

Penelitian Mihret dan Aderajew (2007) melalui studi kasus yang dilakukan di lembaga perguruan tinggi di Ethiopia telah menyoroti efektivitas audit internal sangat dipengaruhi oleh kualitas audit internal dan dukungan manajemen. Hal ini sejalan dengan penelitian Al Matarneh (2011) yang menunjukkan bahwa auditor internal mempertimbangkan kompetensi, objektivitas serta kinerja audit internal sama pentingnya dengan faktor yang mempengaruhi audit internal.

Sistem yang efisien dan efektif, menjaga harta dan integritas data dapat tercapai jika manajemen menyusun sistem pengendalian internal yang memadai sehingga audit internal dapat membantu manajemen dalam mencegah terjadinya fraud. Hal sebaliknya, jika sistem pengendalian internal yang disusun oleh manajemen lemah, maka kemungkinan terjadinya kesalahan, ketidakakuratan, serta kecurangan (fraud) sangat besar (Agoes, 2013).

\section{Kerangka Teoritis}

\section{Peran Audit Internal}

Peran menurut Kamus Besar Bahasa Indonesia (KBBI) adalah perangkat tingkah laku yang diharapakan dimiliki oleh orang yang berkedudukan di masyarakat. Peran mencerminkan posisi seseorang dalam sistem sosial dengan hak dan kewajiban, kekuasaan dan tanggungjawab yang menyertainya. Untuk dapat berinteraksi satu sama lain, maka diperlukan cara tertentu untuk mengantisipasi perilaku orang lain (Agustina, 2009).

Menurut Surat Keputusan Ketua Bapepam dan Lembaga Keuangan Nomor : Kep- 496/BL/2008, audit internal adalah suatu kegiatan pemberian keyakinan (assurance) dan konsultasi yang bersifat independen dan obyektif, dengan tujuan untuk meningkatkan nilai dan memperbaiki operasional perusahaan, melalui pendekatan yang sistematis, dengan cara mengevaluasi dan meningkatkan manajemen risiko, pengendalian, dan proses tata kelola perusahaan. Audit internal dilaksanakan oleh pihak internal dalam organisasi yang dikenal dengan auditor internal.

Peran auditor internal sangat diperlukan dalam suatu organisasi, karena auditor internal merupakan penilai independen untuk menelaah operasional organisasi dan mengevaluasi kecukupan kontrol serta efisiensi dan efektivitas kinerja organisasi. Dalam menjalankan tugasnya auditor internal harus didukung dengan integritas manajemen yang baik. Untuk menjalankan tugasnya dengan baik maka internal auditor harus berada diluar fungsi lini suatu organisasi atau berada di luar hierarchy management tetapi tidak terlepas dari fungsi atasan dan bawahan sebagai bentuk pertanggungjawaban tugas.

\section{Pencegahan Fraud}

Fraud diterjemahkan sebagai penyimpangan, dimana penyimpangan tersebut dilakukan dengan unsur kesengajaan dalam melakukannya. Dalam penelitiannya, Singleton (2010) mendefinisikan fraud sebagai tindakan mengambil keuntungan secara sengaja dengan cara menyalahgunakan suatu pekerjaan/jabatan atau mencuri aset/sumberdaya dalam organisasi.

Tindakan fraud ini dilakukan disebabkan karena 3(tiga) hal, yaitu : 1) Tekanan (pressure), 2) Kesempatan (Opportunity), dan 3) Pembenaran atas tindakan (rationalization). Ketika hal tersebut diatas dikenal dengan The Fraud Triangle (Singleton, 2010). 
Association of Certified Fraud Examination (ACFE) salah satu asosiasi di Amerika yang memfokuskan kegiatannya dalam pencegahan dan pemberantasan penyimpangan. Bentuk penyimpangan dikategorikan menjadi 3 (tiga) yaitu : penyimpangan pelaporan keuangan (fraudulent financial reporting), penyalahgunaan asset (misappropriation asset), dan korupsi (Corruption) (Singelton, 2010).

Sinaga (2008) menjelaskan bahwa fraud mencakup : (1) Penggelapan, (2) Manipulasi pelanggaran karena jabatan, (3) Pencurian, (4) Ketidakjujuran, (5) Kelakuan buruk, (6) Kelalaian, (7) Penggelapan Pajak, (8) Penyuapan, (9) Pemerasan, (10) Penyerobotan, (11) Salah saji, dan (12) Fraudelent. Meskipun demikian, pada dasarnya fraud merupakan serangkaian ketidakberesan mengenai : perbuatan-perbuatan melawan hukum, yang dilakukan secara sengaja untuk tujuan tertentu, yang dilakukan oleh orang-orang dari dalam ataupun dari luar organisasi, untuk mendapatkan keuntungan pribadi maupun kelompok dan secara langsung atau tidak langsung meerugikan pihak lain. Untuk membatasi pembahasan dalam artikel ini, fraud yang dimaksud adalah segala jenis kecurangan di Perguruan Tinggi yang dapat mengakibatkan kerugian keuangan, manfaat serta salah saji dalam pelaporan.

Menurut Tuanakotta (2012) penyebab atau akar masalah dari tindakan fraud adalah fraud by need, fraud by greed and by opportinity, Hal ini mengartikan bahwa ketika fraud ingin dihilangkan maka hilangkanlah faktor dari penyebab fraud itu sendiri. Apabila institusi terbuka dalam hal penyelesaian fraud maka ketika terjadi indikasi fraud, dengan terbuka institusi tersebut memberikan informasi terkait tindakan fraud yang terjadi dalam intitusi. Hal itu akan memberikan efek jera, dan ketika seseorang ingin melakukan tindakan yang sama, maka akan berpikir ulang. Lebih lanjut Tuanakotta (2012) menyatakan bahwa pencegahan fraud dapat dilakukan dengan mengaktifkan pengendalian internal.

Cattrysse (2002) mengatakan bahwa tindakan fraud dapat diminimumkan dengan penerapan corporate governance. Pada penelitiannya, Cattrysse (2002) juga menyatakan bahwa auditor internal yang baik dapat mencegah terjadinya fraud melalui 3 (tiga) alat pencegahan fraud, yaitu: Tata Kelola Perusahaan, pimpinan organisasi yang baik (bersih), dan penerapan internal control.

\section{Tinjauan Pustaka}

TABEL 1

PETA RISET PENELITIAN TERDAHULU

\begin{tabular}{|c|c|c|c|}
\hline Judul & Peneliti & Metodologi & Hasil \\
\hline $\begin{array}{l}\text { Peranan Audit Internal dan } \\
\text { Pencegahan Fraud dalam } \\
\text { Menunjang Efektifitas } \\
\text { Pengendalian Internal }\end{array}$ & $\begin{array}{l}\text { Ety Meikhati } \\
\text { dan Istiyawati } \\
\text { Rahayu }\end{array}$ & $\begin{array}{l}\text { metode } \\
\text { studi } \\
\text { empiris, } \\
\text { yaitu } \\
\text { penelitian } \\
\text { terhadap } \\
\text { fakta } \\
\text { empiris } \\
\text { yang } \\
\text { diperoleh } \\
\text { berdasarkan } \\
\text { observasi } \\
\text { dan } \\
\text { pengalaman. }\end{array}$ & 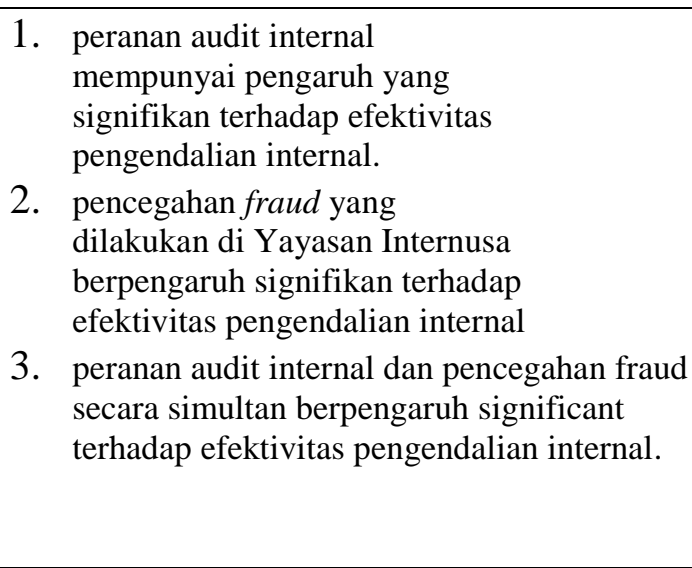 \\
\hline $\begin{array}{l}\text { Pengaruh Peran Audit } \\
\text { Internal dan Pengendalian } \\
\text { Internal terhadap } \\
\text { Pencegahan Fraud }\end{array}$ & Suginam & Regresi & $\begin{array}{l}\text { 1. internal audit berpengaruh terhadap } \\
\text { pencegahan } \\
\text { fraud } \\
\text { 2. Pengendalian Internal berpengaruh positif } \\
\text { (tidak signifikan) terhadap }\end{array}$ \\
\hline
\end{tabular}




\begin{tabular}{|c|c|c|c|}
\hline & & & fraud \\
\hline $\begin{array}{l}\text { Gejala Fraud dan Peran } \\
\text { Auditor Internal dalam } \\
\text { Pendeteksian Fraud Di } \\
\text { Lingkungan Perguruan } \\
\text { Tinggi }\end{array}$ & $\begin{array}{l}\text { Rozmita } \\
\text { Dewi YR dan } \\
\text { R. Nelly Nur } \\
\text { Apandi }\end{array}$ & $\begin{array}{l}\text { Pendekatan } \\
\text { Kualitatif }\end{array}$ & $\begin{array}{l}\text { 1. Auditor internal berpengaruh (tidak signifikan) } \\
\text { dalam upaya mendeteksi terjadinya fraud } \\
\text { 2. manajemen berpengaruh signifikan dalam } \\
\text { upaya mendeteksi bahkan mencegah terjadinya } \\
\text { fraud. }\end{array}$ \\
\hline $\begin{array}{l}\text { The Role of Internal Audit } \\
\text { in Fraud Prevention and } \\
\text { Detection }\end{array}$ & $\begin{array}{l}\text { Daniela } \\
\text { Petradcu dan } \\
\text { Alexandra } \\
\text { Tieanu. }\end{array}$ & $\begin{array}{l}\text { Analisis } \\
\text { kualitatif } \\
\text { dan metode } \\
\text { komparasi }\end{array}$ & $\begin{array}{l}\text { 1. Internal audit dibutuhkan dalam efisiensi bisnis } \\
\text { melalui sistem internal control } \\
\text { 2. Internal control bermanfaat untuk melawan } \\
\text { fraud dan meningkatkan nilai tambah entitas di } \\
\text { masa depan }\end{array}$ \\
\hline $\begin{array}{l}\text { Fraud Detection and } \\
\text { Prevention Methods in the } \\
\text { Malaysian Public Sector : } \\
\text { Accountants and Auditors } \\
\text { Perceptions }\end{array}$ & Othman, et.al. & $\begin{array}{l}\text { Analisis } \\
\text { kuantitatif }\end{array}$ & $\begin{array}{l}\text { 1. Internal auditor dan akuntan di sector } \\
\text { public memiliki peran penting dalam } \\
\text { menditeksi dan mencegah terjaadinya } \\
\text { fraud } \\
\text { 2. Kebijakan wihistle-blowing, fraud } \\
\text { horlines, dan akuntan forensic tidak } \\
\text { berpengarih terhadap pencegahan fraud }\end{array}$ \\
\hline
\end{tabular}

Pada Tabel 1 diatas dijelaskan penelitian terdahulu yang telah dilakukan terkait peran internal audit sebagai internal control dalam pendeteksian serta pencegahan fraud. Penelitian yang dilakukan oleh Suginam (2017) memberikan hasil bahwa peranan audit internal mempunyai pengaruh yang signifikan terhadap efektivitas pengendalian internal, pengendalian internal yang dilakukan oleh organisasi kemudian berpengaruh signifikan terhadap pencegahan terjadinya fraud. Hasil penelitian ini sejalan dengan Petrascu dan Tieanu (2014) yang mengungkapkan bahwa entitas membutuhkan internal audit untuk efisiensi bisnis dalam membentuk manajemen yang baik dalam mengelola entitas. Good governance suatu entitas akan membentuk sistem internal control yang baik sehingga dapat mencegah terjadinya fraud dan memberikan value added di masa yang akan datang.

Othman,et.al (2015) menemukan bahwa mekanisme dalam mendeteksi dan mencegah fraud dapat berupa audit operasional, peningkatan peran komite audit, review dan peningkatan internal control, review terhadap kas, dan kebijakan pelaporan fraud. Mekanisme tersebut merupakan mekanisme yang efektif menurut internal auditor dan akuntan dalam unit sektor publik. Lebih lanjut dalam penelitiannya, Othman.et.al (2015) mengungkapkan bahwa Internal auditor dan akuntan di sektor publik memiliki peran penting dalam menditeksi dan mencegah terjadinya fraud. Sedangkan kebijakan wihistle-blowing, fraud horlines, dan akuntan forensic tidak berpengaruh terhadap pencegahan fraud.

Penelitian lain dilakukan oleh Rozmita (2012) yang menyebutkan bahwa jenis fraud dikelompokan menjadi tiga macam yaitu fraudulent financial statement, misappropriation asset dan korupsi, ketiganya memiliki karakteristik berbeda mengenai mot cccccrvif dan pelaku fraud tersebut atau yang dikenal dengan istilah Fraudster. Bagi organisasi yang

tidak berorientasi pada laba maka misappropriation asset berpotensi lebih sering terjadi dibandingkan dengan jenis fraud lainnya. Disebutkan pula bahwa potensi terjadinya penyalagunaan asset juga sangat mungkin terjadi pada kas. Jumlah dana yang dikelola perguruan tinggi sangat besar. Dimana unit satuan terkecil dalam entitas pengguna dana adalah fakultas/jurusan/program studi. Kelemahan pengendalian intern atas kas juga menyebabkan peluang bagi fraudster untuk melakukan tindakan fraud.

Rozmita (2012) juga mengungkapkan bahwa auditor internal memiliki peran dalam upaya mendeteksi terjadinya fraud akan tetapi peran manajemen puncak jauh lebih penting dalam upaya mendeteksi bahkan mencegah terjadinya fraud. Manajemen puncak melakukan review terhadap pengendalian internal suatu perguruan tinggi dinilai merupakan faktor penting dalam mendeteksi serta mencegah terjadinya 
fraud. Hasil penelitian ini sejalan dengan penelitian yang dilakukan oleh Omar dan Bakar (2012) dengan metode survey terhadap pencegahan fraud yang terjadi pada institusi pemerintah di Malaysia. Omar dan Bakar menemukan bahwa review manajemen terhadap pengendalian internal dan audit eksternal atas laporan keuangan merupakan mekanisme pencegahan fraud yang utama.

\section{Pembahasan}

Perlindungan terbaik sebuah organisasi terhadap pencegahan fraud adalah sistem pengendalian internal yang efektif, serta peran dewan eksekutif, komite audit dan internal audit dalam mengembangkan sistem pengendalian internal (Petrascu dan Tieanu, 2014). Pertama, dewan eksekutif bertanggungjawab dalam implementasi mekanisme dalam mendeteksi dan mencegah fraud dengan menerapkan dan memelihara sistem akuntansi dan internal control yang sesuai. Kedua, komite audit memiliki peran mengawasi risiko terjadinya fraud dan aktif memantau dewan eksekutif dalam melawan terjadinya fraud. Ketiga, internal audit merupakan garis terdepan dalam memantau terjadinya risiko fraud. Internal auditor harus: memiliki pengetahuan yang memadai dalam mengidentifikasi signal kemungkinan terjadinya fraud, waspada terhadap kasus-kasus yang berisiko menimbulkan fraud, serta melakukan investigasi terhadap kasus untuk mengeliminasi atau mengurangi kemungkinan terjadinya fraud (Petrascu dan Tieanu, 2014).

Seiring dengan semakin berkembangnya organisasi sebagai suatu entitas, maka permasalahan kompleks semakin mungkin terjadi dan pengawasan terhadap permasalahan tersebut semakin diperlukan untuk mendeteksi adanya fraud. Peningkatan pengendalian internal menurut COSO (2013) terdiri dari lima elemen yaitu : 1). Lingkungan Pengendalian (Control Environment), 2). Penaksiran Risiko (Risk Assesment), 3). Aktivitas Pengendalian (Activity Control), 4). Informasi dan Komunikasi (Information and Communication), dan 5). Pemantauan (Monitoring). Kelima elemen tersebut dilakukan serta dalam pelaksanaannya diawasi oleh internal audit.

Keberadaan sebuah mekanisme yang dapat membantu memastikan efektivitas pengawasan dalam proses operasional juga merupakan faktor penting dalam pencegahan penyimpangan (fraud). Mekanisme tersebut adalah mengoptimalkan fungsi serta peran internal audit dalam perguruan tinggi. Menurut IIA, audit internal merupakan aktivitas independen, memiliki keyakinan obyektif, dan konsultasi yang dirancang untuk menambah nilai dan meningkatkan operasi organisasi. Audit internal ini membantu organisasi mencapai tujuannya dengan melakukan pendekatan sistematis dan disiplin untuk mengevaluasi dan meningkatkan efektivitas mmanajemen risiko, pengendalian, dan proses tata kelola.

Definisi audit internal mengandung arti bahwa audit internal merupakan suatu aktivitas yang dilakukan untuk membantu manajemen dalam penyediaan informasi, dengan tujuan akhir yaitu menambah nilai perusahaan. Untuk meningkatkan efisiensi dan efektivitas keberadaan internal audit maka berikut beberapa hal yang perlu diperhatikan (Sawyers, 2005) :

a. Departemen internal audit harus memiliki kedudukan independen dalam organisasi, yaitu tidak terlibat dengan kegiatan operasional yang diperiksanya.

b. Departemen internal audit harus memiliki uraian tugas tertulis yang jelas sehingga dapat mengetahui tugas, wewenang, serta tanggungjawabnya. Departemen internal audit harus pula memiliki buku saku manual yang berguna untuk : a) mencegah terjadinya penyimpangan dalam tugas, b) menentukan standar untuk mengukur dan meningkatkn kinerja, c) memberi keyakinan bahwa hasil akhir departemen internal audit telah sesuai dengan permintaan kepala internal audit. 
c. Departemen internal audit harus memiliki dukungan yang kuat dari top management, dukungan tersebut dapat berupa : a) penempatan departemen internal audit dalam posisi yang independent, b) penempatan staf internal audit dengan gaji yang rationable, c) penyediaan waktu yang cukup dari top management untuk membaca, mendengarkan, dan mempelajari laporan-laporan dari departemen internal audit dan memberikan tanggapan yang cepat dan tegas terhadap saran-saran yang diajukan.

d. Departemen internal audit harus memiliki sumber daya yang professional, berkemampuan, dapat bersikap objektif dan mempunyai integritas dan loyalitas yang tinggi.

e. Departemen internal audit harus bersifat kooperatif dengan akuntan publik.

f. Harus diadakannya rotasi dan kewajiban mengambil cuti bagi departemen internal audit.

g. Pemberian sanksi yang tegas kepada pegawai yang melakukan kecurangan atau penyimpangan serta memberikan pengahrgaan kepada pegawai yang berprestasi.

h. Menetapkan kebijakan yang tegas mengenai pemberian-pemberian dari luar.

i.Mengadakan program pelatihan dan pendidikan untuk meningkatkan kemampuan pegawai dalam melaksanakan fungsi dan tugasnya sebagai auditor internal.

Sistem pengendalian internal suatu perguruan tinggi berisi individu-individu yang kemudian disebut dengan internal auditor yang bertugas sesuai dengan tugas pokoknya yang bertujuan untuk pemenuhan tujuan organisasi. Menurut Dana et. al (2008) auditor internal adalah pakar dalam tata kelola, manajemen risiko, dan pengendalian internal. Auditor internal berusaha untuk meningkatkan operasi organisasi dan berupaya untuk mengurangi kemungkinan terjadinya hal negatif termasuk pelaporan keuangan yang tidak dapat diandalkan.

Menurut Anggraini (2008), peran auditor internal berpengaruh secara nyata terhadap pengendalian internal dan kinerja perusahaan. Hal tersebut disebabkan oleh ruang lingkup pekerjaan auditor internal meliputi penilaian dan pengevaluasian terhadap efektivitas sistem pengendalian internal. Perguruan tinggi sebagai organisasi dinilai baik ketika dapat mengoptimalkan fungsi internal audit, karena organisasi yang dapat memfungsikan internal auditnya dengan baik secara umum memiliki kontrol yang lebih baik (Hirth, 2008).

Sesuai dengan Interpretasi Standart Profesional Audit Internal (SPAI)- Standar 120.2 tahun 2004, tentang pengetahuan mengenai penyimpangan, dinyatakan bahwa auditor internal harus memiliki pengetahuan yang memadai untuk dapat mengenali, meneliti, dan menguji adanya indikasi penyimpangan (fraud). Dalam memenuhi tujuan organisasi, fraud yang mungkin terjadi harus dideteksi, dikelola dan dihindari.

Auditor internal dituntut harus memiliki kompetensi yang memadai untuk memenuhi tugasnya dalam mencegah terjadinya fraud. Menurut Sawyer et.al (2005), kompetensi auditor internal adalah sebuah hubungan cara-cara setiap auditor memanfaatkan pengetahuan, keahlian, dan pengalaman. Menurut Standar Kompetensi Auditor (BPKP, 2010) disebutkan bahwa auditor harus memiliki kemampuan mencakup :

1) Pengetahuan, ini mencakup fakta, informasi, dan keahlian yang diperoleh seseorang melalui pendidikan, baik secara teori maupun pemahaman praktis.

2) Keterampilan/Keahlian, merupakan kemampuan untuk melakukan tugas dengan baik atau lebih baik dari rata-rata. 
3) Sikap perilaku, hal ini mewakili rasa suka atau tidak seseorang pada suatu hal. Kompetensi dari aspek sikap perilaku ini merupakan segala sikap perilaku yang harus dimiliki auditor disemua jenjang atau tingkat jabatan.

Semakin besar lingkup sebuah organisasi maka risiko terjadinya fraud akan semakin tinggi. Risiko fraud merupakan kerentanan yang dihadapi oleh organisasi terkait dengan unsur fraud triangle (motif, kesempatan, dan rasionalisasi) yang terjadi dari sisi internal maupun eksternal. Risiko ini merupakan bagian dari risiko bisnis yang berdampak pada timbulnya kerugian materi seperti uang, peralatan, asset tetap, dan rusaknya reputasi perguruan tinggi. Risiko fraud ini bukan hanya mencerminkan sesuatu yang sudah terjadi tetapi dapat berupa situasi atau kejadian yang berkontribusi terhadap akan terjadinya peristiwa fraud (IAI, 2017). Berikut merupakan cara menglola adanya risiko fraud yang mungkin terjadi (IAI, 2017):

\section{a. Prevention}

1) Membangun etika dan budaya kejujuran dan amanah

2) Hilangkan kesempatan (mengembangkan sistem pengendalian internal)

b. Detection

1) Kenali gejala adanya fraud

2) Perhatikan gaya hidup yang tidak wajar

3) Adanya saluran pengaduan

c. Investigation

1) Pembuktian adanya fraud

d. Legal Aspect

1) Sanksi administratif

2) Sanksi pidana

3) Gugatan perdata atas kerugian organisasi/ kerugian negara

Menurut penelitian Singleton (2010), upaya untuk mengurangi tindakan fraud dibagi menjadi 3 (tiga) fase. Pada fase pertama yaitu fase pencegahan tindakan fraud. Cara yang paling efektif adalah melalui perubahan perilaku dan budaya organisasi yang memberikan perhatian lebih atas tindakan kecurangan. Upaya yang dilakukan adalah melalui struktur corporate governance, tone at the top, penentuan tujuan yang realistis dan kebijakan serta prosedur yang dapat mencegah tindakan penyimpangan. Pendapat lain mengemukakan bahwa cara untuk mencegah tindakan fraud dapat dilakukan melalui upaya menciptakan budaya kejujuran, sikap keterbukaan dan meminimalisasi kesempatan untuk melakukan tindakan fraud (Albercht, 2003).

Fase kedua yaitu pendeteksian tindakan fraud dapat dilakukan dengan cara pengamatan (surveillance), anonymous tips, audit mendadak, melakukan tuntutan hukum, penegakan etika, dan kebijakan atas tindakan fraud. Hal lainnya yang dapat mengurangi tindakan fraud adalah memberikan penghargaan kepada pegawai yang telah berkontribusi dalam mendeteksi perilaku kecurangan serta menegakkan budaya anti fraud. Tahap deteksi atas tindakan fraud berbeda dengan tahap invertigasi, pada tahap ini berupaya mengidentifikasi yang sering terjadi dan mengarah pada tindakan fraud.

Fase ketiga adalah investigasi tindakan fraud, pada tahap ini dilakukan investigasi untuk menentukan siapa yang melakukan fraud, skema apa yang dilakukan dalam tindakan fraud, kapan melakukannya, apa motivasinya, dan berapa jumlah uang atau asset yang sudah diambil (Albercht, 2003).

Pihak manajemen menyusun konsep pengendalian internal yang baik pada perguruan tinggi dalam meminimalisir terjadinya fraud. Pengendalian interal tersebut berupa penyusunan Standar Operasional Prosedur (SOP) untuk setiap transaksi dan kegiatan dalam organisasi, pengawasan jalannya SOP baik di unit pusat maupun di fakultas, serta pembentukan tim pengawas pengendalian internal atau disebut Satuan Pengawas Internal (SPI). Tim Satuan Pengawas Internal menjalankan fungsi audit internal bagi perguruan tinggi. Fungsi ini berperan dalam mengawasi dijalankannya SOP oleh setiap pihak yang telah ditetapkan oleh manajemen perguruan tinggi, melakukan review serta kegiatan 
audit, memberikan rekomendasi ketika terjadi ketidaksesuaian serta memantau apakah rekomendasi telah dilakukan.

Kegiatan pengawasan yang dilakukan oleh tim internal audit perguruan tinggi diharapakan dapat mencegah terjadinya fraud. Karena ketika setiap transaksi dan kegiatan telah sesuai dengan SOP yang berlaku, dan pihak pelaksana sadar atas kapasitas, tanggungjawab serta hak nya, maka diharapkan fraud dapat dideteksi serta dicegah.

\section{Kesimpulan}

Menurut Undang-Undang nomor 12 tahun 2012 tentang pendidikan tinggi, pasal 64 menyatakan bahwa otonomi pengelolaan di perguruan tinggi meliputi bidang akademik dan bidang non akademik. Otonomi pengelolaan di bidang akademik meliputi penetapan norma dan kebijakan operasional serta pelaksanaan tridharma. Sedangkan otonomi di bidang non akademik meliputi penetapan norma dan kebijakan operasional serta pelaksanaan organisasi, kemahasiswaan, keuangan, ketenagaan, dan sarana prasarana.

Sistem internal control yang dibangun pihak perguruan tinggi, yang terdiri dari dewan eksekutif, komite audit, serta internal audit diharapkan dapat menanggulangi penyelewengan (fraud) yang mungkin terjadi dalam pengelolaan baik di bidang akademik dan non akademik. Internal audit merupakan garis terdepan dalam pelaksanaan internal control suatu perguruan tinggi dalam mengawasi jalannya sistem pengelolaan perguruan tinggi sehingga menghasilkan pelaporan yang dapat diandalkan serta mencegah terjadinya tindakan penyelewengan (fraud).

Kompetensi dari internal auditor juga sangat berpengaruh dalam mencegah terjadinya fraud di perguruan tinggi. Hal ini terkait dengan Interpretasi Standart Profesional Audit Internal (SPAI)- Standar 120.2 tahun 2004, tentang pengetahuan mengenai penyimpangan, dinyatakan bahwa auditor internal harus memiliki pengetahuan yang memadai untuk dapat mengenali, meneliti, dan menguji adanya indikasi penyimpangan (fraud).

\section{Daftar Pustaka}

Agoes. Sukrisno. 2013. Auditing Petunjuk Praktis Pemeriksaan Akuntan oleh Akuntan Publik Edisi 4. Jakarta. Salemba Empat

Agustina, Lidya. 2009. Pengaruh Konflik Pesan, Ketidakjelasan Peran, dan Kelebihan Peran terhadap Kepuasan Kerja dan Kinerja Auditor. Jurnal Akuntansi, Bandung

Albrecht, W.S. 2003. Fraud Examination. South Western : Thompson

Al Matarneh, Ghassan. F. 2011. Factors Determining the InternalAudit Quality in Banks : Empirical Evidence from Jordan. International Research Journal of Finance and Economics, 73. Pp 99-108

Anggraini, Fitria. 2008. Analisis Pengaruh Peran Auditor Internal terhadap Peningkatan Pengendalian Intern dan Kinerja Perusahaan. Skripsi Universitas Islam Negeri Syarif Hidayatullah. Jakarta

BPKP. 2010. Peraturan Kepala Badan Pengawasan Keuangan dan Pembangunan Nomor : PER-211/K/JF/2010 tentang Standar Kompetensi Auditor. Jakarta

Cattrysse. 2002. Reflections on Corporate Governance and the Role of Internal Auditor. Final Paper Master in Internal Auditing.

COSO. 2013. COSO Framework and SOX Compliance. PDF Version. http: //www.coso.org

Dana, R Hermanson, et.al. 2008. Building on Effevtive Internal Audit Function : Learning from SOX Section 404. Review of Business. Winter Vol. 2. Pp 28

Dewi dan Apandi. 2011. Gejala Fraud dan Peran Auditor Internal dalam Pendeteksian Fraud di Lingkungan Perguruan Tinggi . UPI

Hirth, Robert B. 2008. Better Internal Audit Leads to Better Control. Vol 24. Morristown 
IAI. 2017. Workshop Forensic Accounting VS Investigative Audit. Jakarta

Josiah, Mary. Adediran A. Samson. Dan Akpeti O. Elizabeth. 2012. Evaluation of Roles of Auditors in the Fraud Detection and Investigation in Nigerian Industries. American Journal of Social and Management Sciences 3 (2). Pp 49-59

Mihret, D.G dan Aderajew W. Yismaw. 2007. Internal Audit Effectiveness : an Ethiopian Public Sector Case Study. Managerial Auditing Journal, 22 (5). Pp 470-484

Othman, Rohana.et.al. 2015. Fraud Detection and Prevention Methods in the Malaysian Public Sector : Accountants' and Internal Auditors' Perceptions. $7^{\text {th }}$ International Conference on Financial Criminology. Oxford, United Kingdom.

Petrascu, Daniela dan Alexandra Tieanu. 2014. The Role of Internal Audit in Fraud Prevention and Detection. $21^{\text {st }}$ International Economic Conference. Sibiu. Romania

Rozmita, Dwi dan R. Nelly Nur Apandi . 2012. Gejala Fraud dan Peran Auditor Internal dalam Pendeteksian Fraud di Lingkungan Perguruan Tinggi (Studi Kualitatif). Makalah SNA Akuntansi Unikal.

Sawyer, B. Lawrence.et. al. 2005. Internal Auditing. The IIA : Salemba Empat

Sinaga, N. S.B. 2008. Peranan Keahlian Internal Auditor dalam Mencegah dan Mendeteksi Kecurangan (Fraud). Fakultas Ekonomi. Universitas Trisakti

Singleton. 2010. Fraud Auditing and Forensic Accounting. Fourth Edition. Wiley Corporate

Surat Keputusan Ketua Bapepamm dan Lembaga Keuangan Kep-496/BL/2008 Tentang Pembentukan dan Pedoman Penyusunan Piagam Unit Audit Internal.
Tuanakotta, T., M. 2012. Akuntansi Forensik dan Audit Investigasi. Jakarta : Salemba Empat

Zakaria, Zamzulaina., Susela Devi S., dan Zarina, Zakaria. 2006. Internal Auditors: Their Roles in Institutions of Higher Education in Malaysia, Managerial Auditing Journals. Vol 21 Iss:9, PP.892-904 